\title{
Genetically influenced resistance to stress and disease in salmonids in relation to present-day breeding practice - a short review
}

\author{
Jan Mendel $^{1}$, Kristýna Jánová ${ }^{2}$ Miroslava Palíková ${ }^{2}$ \\ ${ }^{1}$ Institute of Vertebrate Biology, Czech Academy of Sciences, Brno, Czech Republic \\ ${ }^{2}$ University of Veterinary and Pharmaceutical Sciences Brno, Faculty of Veterinary Hygiene and Ecology, \\ Department of Ecology and Disease of Game, Fish and Bees, Brno, Czech Republic
}

Received October 6, 2017

Accepted April 3, 2018

\begin{abstract}
While intensive fish production has many advantages, it also has a number of drawbacks as regards disease and stress. To date, there has been no conclusive review of disease resistance at Czech fish farms. The aim of the study was to describe briefly the existing salmonid breeding practice in the Czech Republic and to point out the trends and new possibilities gaining ground around Europe. However, the present situation in the Czech stocks is not rare at all and therefore it is used here as a model example representing numerous breeding practices in Europe. Stress and disease resistance in fish is polygenic and quantitative, making selection for such traits difficult. In recent years, however, fish breeding methods have developed rapidly, with the use of genetic analysis tools, for example, now allowing much greater selection accuracy. Gradual progress in understanding the importance of individual genetic markers offers many new options that can be utilised in breeding practice. New selection methods, such as quantitative trait loci (QTLs) and genomic selection, are increasingly employed in European aquaculture. Next generation sequencing techniques now help in the finding of new and promising QTLs that can be used in assisted selection. This review maps the current progress in improving salmonid resistance to stress and disease in aquaculture and at the same time provides the breeders with a short overview of the latest tools of genetically controlled breeding and of the newest products available at the European market.
\end{abstract}

Disease resistance, quantitative trait loci, marker assisted selection, genomic selection, molecular breeding, rainbow trout, brook trout

Over the past few decades, aquaculture, and especially intensive aquaculture, has grown considerably as a source of food production, both in the Czech Republic and around the world. At $4 \%$ of total fish production (ca 700 tonnes p.a.), intensive aquaculture plays a relatively minor role in Czech fish production, which is primarily based on semi-intensive culturing of carp (Cyprinus carpio) in open earth ponds at relatively low stocking densities (Horký 2016). In intensive Czech trout aquaculture, the main species farmed are the non-native salmonids rainbow trout (Oncorhynchus mykiss) and brook trout (Salvelinus fontinalis), other species being of negligible importance. In addition to a wide range of other issues, such as oxygen depletion, flooding, increased predation, chemical poisoning and theft (Palík ová et al. 2015a), intensive fish production has greatly increased the risk of spreading infectious diseases. Many infectious and parasitic diseases have the potential to cause economically important losses in salmonid fish farming, some of the most important being infectious haematopoietic necrosis (IHN), viral haemorrhagic septicaemia (VHS), bacterial diseases such as flavobacteriosis, furunculosis and enteric redmouth disease (ERM), and parasitic diseases such as proliferative kidney disease (PKD) (Palíková et al. 2015b).

Address for correspondence:

MSc. Jan Mendel, Ph.D.

Institute of Vertebrate Biology,

Czech Academy of Sciences

Květná 8, 60365 Brno, Czech Republic

Phone: +420543422533

Email: jmendel@seznam.cz

http://actavet.vfu.cz/ 
While disease prevalence has been widely studied in the Czech Republic and elsewhere, there has been no conclusive review of disease resistance in Czech farmed salmonids, nor any review of the traits associated with pathogen resistance. Similar issues arise in relation to stress response and its role as an important fitness trait. Stress, which has been associated with pathogen infection, fish manipulation and vaccination, can directly or indirectly affect disease resistance (Iversen et al. 1998; Barton 2002). Finally, in temperate regions, the role of thermo-tolerance in particular is growing in importance due to long-term global warming and short-term climatic fluctuations.

Fish breeding methodologies have developed rapidly in recent decades (Janssen et al. 2017). In addition to improvements in nutrition, welfare and water quality, modern genetic methods using immunological and molecular markers have largely overtaken more traditional methods for improving disease resistance based on direct selection of individual fish showing these economically important traits (Gjedrem 2012). While such breeding techniques have the potential to increase breed efficiency, they are still relatively underused, with genetically-modified fish representing less than $10 \%$ of global fish production (Gjedrem et al. 2012). Location of the genomic regions influencing stress response and disease resistance has great potential for improving fish management and production.

In the following review, we provide a short overview of both historical and modern methods used for increasing disease resistance in salmonid strains, lineages and populations in breeding facilities.

\section{Conventional methods of selection for stress and disease resistances}

Breeding practices aimed at improving the production characteristics of salmonids, and especially those of artificially bred rainbow trout, have a long tradition outside of the Czech Republic. In the past, two methods of genetic improvement were mainly used: purebreeding and cross-breeding. Pure-breeding relies on the additive component of genetic variance, whereas cross-breeding between breeds and lineages utilises both the additive and non-additive components and development of a heterotic effect. In the case of charr (Salvelinus fontinalis, Salvelinus alpinus and their hybrids), interspecific hybridisation has also been used (e.g. "Elsässer Saibling" or "Sparctic charr"; Dumas et al. 1996; Reiter 2006). During artificial selection, both stabilisation and directional selection are commonly used ( $\mathrm{Gj}$ edrem 2005), followed by selection for one or more quantitative traits, especially growth characteristics. Regarding selection of individuals, either individual selection, family selection or a combination of both has been used (Janssen et al. 2017). The individuals selected are then subjected to either single-stage or multiple-stage selection. As an example, when evaluating health status, ill individuals are eliminated during negative selection and only individuals meeting the selection criterion are kept during positive selection. During direct selection, individuals with the required trait are selected on the basis of phenotypic values, while a trait in genetic correlation is used during indirect selection as it can be measured more easily. In selection for disease resistance, for example, immuno-physiological indicators, such as haemolytic activity, antibody titre and cortisol level are used (Fevolden et al. 1992; Roed et al. 2002; Weber and Vallejo 2008).

Selective breeding is commonly based on challenge testing for specific pathogens (Ødegård et al. 2011) on individuals showing genetic variance (Brännäs 2000). Selection is expected to be highly effective due to high fish fecundity and high heritability of disease traits (Ødegård et al. 2011), which leads to better disease resistance (Table 1). Older literature describes achievements in improving the resistance of rainbow trout and brook trout to furunculosis (Ehlinger 1977) and the production of rainbow trout lineages strongly resistant against pancreatic necrosis (Okamoto et al. 1993). Other authors 
Table 1. Overview of selected diseases and disease resistance heritability in rainbow trout (Oncorhynchus mykiss) and brook trout (Salvelinus fontinalis).

\begin{tabular}{llcl}
\hline Fish species & \multicolumn{1}{c}{ Causative agent (disease) } & $\begin{array}{c}\text { Heritability of disease } \\
\text { resistance }\left(\mathrm{h}^{2} \pm \mathrm{SE}\right)\end{array}$ & References \\
\hline Brook trout & Aeromonas salmonicida & $0.51 \pm 0.03$ & Perry et al. 2004 \\
Rainbow trout & Yersinia ruckeri (ERM) & $0.21 \pm 0.05$ & Henryon et al. 2005 \\
& Flavobacterium psychrophilum & $0.35 \pm 0.09$ & Silverstein et al. 2009 \\
& Flavobacterium psychrophilum & $0.23 \pm 0.03$ & Leeds et al. 2010 \\
& Flavobacterium psychrophilum & $0.53 \pm 0.09$ & Vallejo et al. 2010 \\
& Flavobacterium psychrophilum & $0.07 \pm 0.02$ & Henryon et al. 2005 \\
& VHS & $0.63 \pm 0.26$ & Dorson et al. 1995 \\
& VHS & $0.11 \pm 0.10$ & Henryon et al. 2005 \\
\hline
\end{tabular}

ERM - enteric redmouth disease; VHS - viral haemorrhagic septicaemia

point to a positive genetic correlation in resistance to a range of bacterial diseases, with improved resistance to a single disease positively influencing resistance to other diseases (Vehviläinen et al. 2008; Ødegård et al. 2011). On the other hand, a negative genetic correlation has been observed as regards viral diseases (Henryon et al. 2005). Positive genetic correlations have also been noted between resistance and other traits, such as growth (Overturf et al. 2010).

The breeding practice in the Czech Republic was, and in most cases still is, based on an estimation of the breeding value of strains and populations according to observed phenotypic values in related individuals using simple statistical methods (i.e. conventional phenotypic selection). This is also true for the intensive breeding of rainbow trout in the Czech Republic, which is mainly performed on several populations from which historical lineage stocks also originate (Flajšhans et al. 2013):

1) Pd M (rainbow trout, local form), characterised (among other things) by high stress resistance;

2) PdD 66 (imported from Denmark in 1966; original source Lake Kamloops), characterised by low stress resistance;

3) PdD 75 (imported from Denmark in 1975), characterised (among other things) by differing genetic traits than the two preceding forms, and by eggs that show increased resistance to low water temperatures.

These three historical strains are presently long-term sustained by the Ministry of Agriculture under the 'National Programme on Conservation and Utilisation of Plant, Animal and Microbial Genetic Resources for Food and Agriculture'. About four stocks with these strains are presently supported in the Czech Republic (Flajšhans et al. 2009).

Compared with stocks of rainbow trout, which represent the greater part of salmonid market production in the Czech Republic, the breeding of charr plays a minor role. As such, no national breeding programmes have been developed and no concrete lineage stocks founded or financially supported.

At present, it is up to Czech breeders whether they keep their own breeding nucleus or use imports from domestic or foreign suppliers. Similarly, Czech breeders may use improved breeding material with or without any knowledge of genetics. Indeed, salmonid selection programmes using molecular genetics are still in their infancy in the Czech Republic. Aquacultural breeding programmes for improving the genetic make-up of fish are not a new phenomenon in Europe. The first "modern" national fish breeding programme based on selective breeding took place in Norway in the 1970s with the aim of supporting 
the growing commercial production of rainbow trout and Atlantic salmon (Salmo salar L.) (Gjedrem 2000; Janssen et al. 2017). The first breeding programmes using family selection focused on growth, sexual maturation, skin colour, body shape, fillet colour and fillet yield (Fig. 1). Only recently have breeding programmes aimed at increasing disease resistance, with a programme focused on infectious pancreatic necrosis (IPN) resistance starting in 2009, and another one on flavobacteriosis resistance in 2016. Since 2015, both studies have been controlled using quantitative trait loci (QTLs) selection (AquaGen 2017a). Rather than being restricted to local use, however, these resistant lineages are already being offered for export to other countries (AquaGen 2017b).

\begin{tabular}{l|l|l|l|l|l|l|l|} 
Measured traits & 1980 & 1995 & 2000 & 2005 & 2010 & 2015 & 2017 \\
\hline Growth in Seawater & & & & & & & \\
\hline Sexual Maturation & & & & & & & \\
\hline Skin Colour & & & & & & & \\
\hline Body Shape & & & & & & & \\
\hline Fillet Colour & & & & & & & \\
\hline Growth in Freshwater & & & & & & & \\
\hline Fillet yield & & & & & & & \\
Skeletal deformities & & & & & & & \\
IPN & & & & & & & \\
\hline Flavobacteriosis & & & & & & & \\
\hline
\end{tabular}

Fig. 1. Main traits measured, selected and controlled in the breeding programme in relation to year of implementation and selection method (AquaGen 2017a)

IPN - infectious pancreatic necrosis; QTL - quantitative trait locus

\section{Selection for improved disease resistance based on genomic analysis}

It should be noted that we are not discussing the development of genetically modified organisms (GMOs) here (i.e. the development of genetically improved aquaculture stocks using genetic engineering techniques); rather, we discuss selective breeding based on natural processes and the latest molecular genetic monitoring methods.

While the present level of knowledge needed to develop effective salmonid breeding programmes is relatively extensive, it is still insufficient. This is mainly due to the widely held belief that disease resistance is a polygenic trait in fish, including salmonids (Rye 2012; Sea 2008). Unfortunately, the actual number of genes responsible is still unknown and there is some uncertainty regarding the actual share of individual genes in the representation of traits. By gradual mapping of the whole genomes, specific deoxyribonucleic acid (DNA) regions (genetic markers) displaying classic Mendelian heredity, measurable degrees of length polymorphism and specific structures can be detected on chromosomes. These regions, with their wide genome distribution and high rates of polymorphism (Das and Sahoo 2014; Jingou and Xiaowen 2015), may serve as substitutes for traits, which may otherwise be too expensive or difficult to measure.

While field studies using traditional breeding and selection methods can provide important information as regards the breeding of resistant stock, new genomic and molecular approaches are providing additional information with great potential to improve selective breeding programmes (e.g. the Danish Company AquaSearch; AquaSearch 2017) and improve selection accuracy and intensity in many traits (Rye 2012). Examination of phenotype/genotype variance and variance in traits associated with resistance could increase our knowledge of the basic genetic architecture of fish resistance to stress and 
disease (Ozaki et al. 2001; Cauwelier et al. 2010; Rexroad et al. 2012). Such genomic resources have already been used for identifying the genetic factors associated with disease resistance in salmonids (Yáñez et al. 2014), the results having been used for identifying QTLs and marker assisted selection (MAS). Quantitative trait loci have now been detected for a variety of economic traits of evolutionary importance in fish, including life history, meristic and morphological, behavioural and thermal tolerance traits as well as traits bestowing disease and parasite resistance through development of the various linkage maps (Nichols et al. 2003b; Wenne et al. 2007).

Significant interdependence observed between variance in phenotype values of some quantitative traits and DNA polymorphism in specific genetic markers in individual populations is now being gradually implemented into breeding programmes through gene assisted selection or MAS (Ødegård et al. 2011; Rye 2012; Janssen et al. 2015, 2017), including those aimed at enhancing resistance to disease (Ozaki et al. 2001). The MAS generally consists of two steps, detection of molecular markers associated with QTL (Table 2) and application of those markers for genetic improvement of local lineages, stocks or populations (Laghari et al. 2014). The MAS has a number of economic and practical advantages for QTL checking, and is especially useful for traits that are difficult to breed using traditional means (Wenne et al. 2007). To date, the majority of breeding programmes utilising relationships between QTL and disease resistance have focussed on rainbow trout, rather than species of the genus Salvelinus (Table 2). On the other hand, the most intensive breeding programme taking place at present focusses on Atlantic salmon, with commercial product lines of fish eggs originating from QTL and genomic selection available since 2016 (AquaGen 2017c).

In recent years, a number of new molecular genetic approaches have been developed for detection of genetic markers associated with QTLs, including allozyme markers, random amplified polymorphic DNA (RAPD), restriction fragment length polymorphism (RFLP) and amplified fragment length polymorphism (AFLP), along with fragmentation analysis of microsatellites and single nucleotide polymorphism (SNP) analysis (Laghari et al. 2014). Most recently, next generation sequencing (NGS) methodologies have been used over a range of identification process phases. The NGS technologies are capable of rapidly identifying thousands of genomic markers, in a cost-effective manner, across almost any genome of interest in a single step (Laghari et al. 2014). At present, only a restricted number of QTLs are known in aquaculture and their utilisation for MAS is mostly still at the stage of experimental programmes in various countries (in the case of salmonid breeding without participation of the Czech Republic). Nevertheless, the first scientific results of this research have already been commercialised and introduced into product lines (see internet sources to AquaGen and AquaSearch above).

Further major advances are expected from the European research project FishBoost (Janssen et al. 2015; FishBoost 2017), supported under the $7^{\text {th }}$ EU Framework Programme. Based on cooperation between 14 research and development partners, 11 industrial partners and the Federation of European Aquaculture Producers (FEAP), this international project aims to increase disease resistance (amongst other aims) through selective breeding of the six most important European commercial species (i.e. Atlantic salmon, rainbow trout, gilthead seabream Sparus aurata, European seabass Dicentrarchus labrax, turbot Scophthalmus maximus and common carp Cyprinus carpio), thereby improving the efficiency and profitability of European aquaculture. Many of the project's goals are related to the topic of this review, including the evaluation of genetic relationships between disease resistance and production traits; quantification of genetic variation in important traits, including disease resistance; and use of the latest genomic techniques to uncover the genetic architecture of resistance to major viral, bacterial and parasitic diseases (e.g. flavobacteriosis in rainbow trout). Thus far, FishBoost has successfully performed 


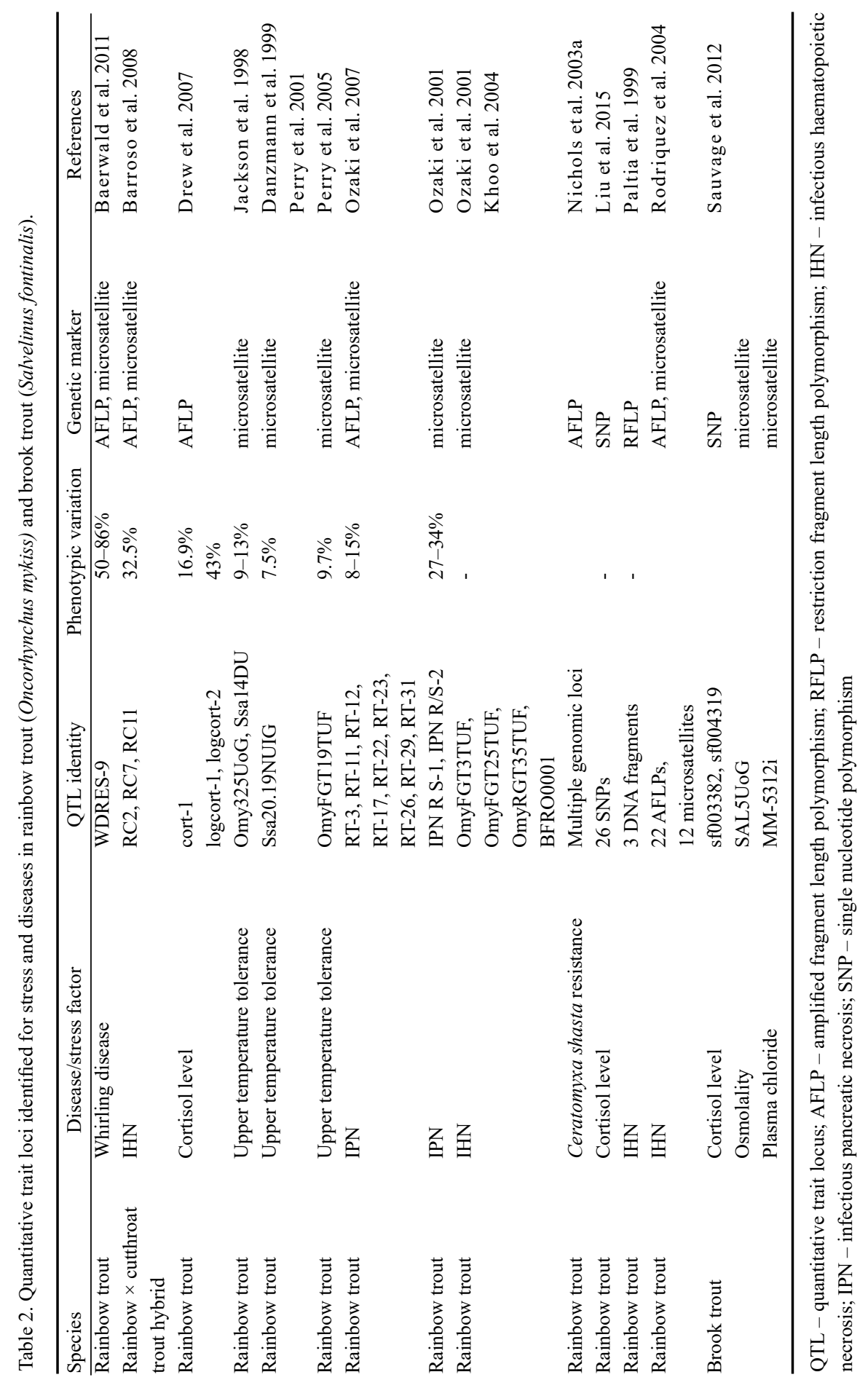


large-scale disease challenge experiments on rainbow trout regarding the rainbow trout fry syndrome (RTFS). Individual fish samples have been genotyped using a range of restriction-site associated DNA sequencing approaches (RAD-seq), which combine the use of genome complexity reduction with restriction enzymes and the high sequencing output of NGS, with the aim of mapping genes for disease resistance traits and calculating genomic breeding values.

\section{Major histocompatibility complex}

Parasite hosts have developed numerous mechanisms to resist infection, including the major histocompatibility complex (MHC), which allows the host's acquired immune system to recognise foreign molecules. As such, the MHC system plays a key role in interactions between the host's immune system and that of the pathogen, being involved in the induction and regulation of immune responses (Lamaze et al. 2014). The MHC genes encode MHC molecules that display a considerable range of polymorphism. The MHC molecules themselves are antigens (glycoproteins) situated on the surface or plasma membrane of cells (Liu et al. 2013). The MHC system contains class I, II and III genes, with class I producing mainly viral antigens and class II mainly bacterial antigens (Markrigiannis and Anderson 2003). Alleles closely related to disease resistance can be used as genetic markers (Liu et al. 2013) and those for IHN (Paltia et al. 2001; Liu et al. 2013), temperature regulation (Nath et al. 2006), bacterial cold water disease (BCWD; Johnson et al. 2008) and IPN resistance (Ozaki et al. 2007) have all now been determined for rainbow trout.

\section{Vaccination}

One of the most common ways to increase fish resistance to pathogens is vaccination with either recombinant proteins, DNA or inactivated pathogens (Corbeil et al. 2000; Melamed et al. 2002; Sommerset et al. 2005; Plant et al. 2009). In recent years the number of pathogen vaccines available has increased dramatically, with many commercial vaccines now available on the market (Sommerset et al. 2005; Magnadottir 2010). The effectiveness of vaccines is higher for viral diseases than for bacterial diseases. At present, however, there are no vaccines available against fish parasites (Sommerset et al. 2005). In the Czech Republic, vaccination is still at a relatively low level. Vaccination is possible only against selected diseases, but not against dangerous diseases (listed on OIE) according to the legislative rules. Rainbow trout, for example, can be vaccinated against furunculosis and ERM, but not against VHS or IHN (Palíková et al. 2015a).

One problem related to vaccination, however, is the possibility that resistance heritability is reduced. In a study of resistance to furunculosis in Atlantic salmon, genetic analysis indicated a low genetic correlation $(0.32 \pm 0.13)$ for disease resistance in vaccinated and unvaccinated fish (Drangsholt et al. 2011).

\section{Conclusion}

In this review, we examined selective breeding and modern molecular techniques used for improving salmonid resistance to stress and disease in aquaculture, with emphasis on salmonid farming in the Czech Republic. Genetic improvement programmes based on such methods tend to be expensive and time-consuming; hence, foreign breeders and fish farmers (including those from the Czech Republic) often join international breeding programmes, from which they can gain up-to-date information and try new commercial products with the potential to make aquaculture more efficient, profitable and sustainable. 
The main task for the future is to incorporate molecular information into breeding programmes. Recent advances in molecular biotechnology have revolutionised the aquacultural industry, the use of molecular markers allowing for the identification of increasing numbers of QTLs connected with stress and disease resistance. At present, there is a clear need to focus on the most common fish diseases in the Czech Republic, i.e. VHS and IHN, BCWD, furunculosis and yersiniosis, PKD and a range of ectoparasitic infections (e.g. ichtyobodosis, ichthyophthiriosis and monogeneans). It is now widely accepted that investment in effective breeding programs results in a high long-term return, with cumulative and permanent selection responses in the target population (Rye 2012). Identification of potential genetic loci and their active use in selection processes, therefore, will be of fundamental importance for the future health and competitive ability of salmonid stocks in the Czech Republic, allowing them to compete on an equal basis with fish farmers and breeders around the world.

\section{Acknowledgements}

This study was carried out within the framework of research project No. QJ1510077, supported by the Ministry of Agriculture of the Czech Republic, and through institutional support RVO: 68081766 . We thank Kevin Roche for help with the English language correction.

\section{References}

AquaGen 2017a: Product documentation for rainbow trout. General product presentation of AquaGen's rainbow trout eggs 2018. AquaGen Web site. Available at: https:/aquagen.no/wp-content/uploads/2017/08/aquagenrainbow-trout-eggs-2018.pdf. Accessed September 14, 2017

AquaGen 2017b: Product portfolio for rainbow trout 2018. AquaGen Web site. Available at: https://aquagen.no/ en/products/trout-eggs/produktoversikt-pa-regnbueorret-2017/. Accessed September 14, 2017

AquaGen 2017c: Salmon eggs 2017/2018. AquaGen Web site. Available at: https://aquagen.no/wp-content/ uploads/2017/08/aquagen-salmon-eggs-2017-2018.pdf. Accessed September 14, 2017

AquaSearch 2017: AquaSearch Web site. Available at: http://aquasearch.dk/breeding-and-innovation/breedingprogramme/. Accessed September 14, 2017

Baerwald MR, Petersen JL, Hedrick RP, Schisler GJ, May B 2011: A major effect quantitative trait locus for whirling disease resistance identified in rainbow trout (Oncorhynchus mykiss). Heredity 106: 920-26

Barroso RM, Wheeler PA, LaPatra SE, Drew RE, Thorgaard GH 2008: QTL for IHNV resistance and growth identified in a rainbow (Oncorhynchus mykiss) x Yellowstone cutthroat (Oncorhynchus clarki bouvieri) trout cross. Aquaculture 277: 156-163

Barton BA 2002 Stress in fishes: A diversity of responses with particular reference to changes in circulating corticosteroids. Integr Comp Biol 42: 517-525

Brännäs E 2000: Breeding programmes of salmonid fish with arctic charr as a case study of relative productivity $\%$. Heredity 91: 60-69

Cauwelier EJ, Gilbey CS, Jones LR, Noble E, Verspoor E 2010: Genotypic and phenotypic correlates with proliferative kidney disease-induced mortality in Atlantic salmon. Dis Aquat Org 89: 125-135

Corbeil S, LaPatra SE, Anderson ED, Kurath G 2000: Nanogram quantities of a DNA vaccine protect rainbow trout fry against heterologous strains of infectious hematopoietic necrosis virus. Vaccine 18: 2817-2824

Danzmann RG, Jackson TR, Ferguson MM 1999: Epistasis in allelic expression at upper temperature tolerance QTL in rainbow trout. Aquaculture 173: 45-58

Das S, Sahoo PK 2014 Markers for selection of disease resistance in fish: a review. Aquacult Int 22: 1793-1812

Dorson ME, Quillet MG, Hollebecq C, Torhy, Chevassus, B 1995: Selection of rainbow trout resistant to viral haemorrhagic septicaemia virus and transmission of resistance by gynogenesis. Vet Res 26: 361-368

Drangsholt TMK, Gjerde B, Ødegård J, Finne-Fridell F, Evensen Ø, Bentsen HB 2011: Quantitative genetics of disease resistance in vaccinated and unvaccinated Atlantic salmon (Salmo salar L.). Heredity 107: 471-477

Drew RE, Schwabl H, Wheeler PA, Thorgaard GH 2007: Detection of QTL influencing cortisol levels in rainbow trout (Oncorhynchus mykiss). Aquaculture 272: S183-S194

Dumas S, Blanc JM, Vallée F, de la Noüe J 1996: Survival, growth, sexual maturation and reproduction of brook charr, Salvelinus fontinalis (Mitchill), Arctic charr, Salvelinus alpinus L., and their hybrids. Aquacult Res 27: 245-253

Ehlinger NF 1977 Selective breeding of trout for resistence to furunculosis. NY Fish Game J 24: 25-36 
Fevolden SE, Refstie T, Roed KH 1992 Disease resistance in rainbow trout (Oncorhynchus mykiss) selected for stress response. Aquaculture 104: 19-29

FishBoost 2017. FishBoost Web site. Available at: http://www.fishboost.eu. Accessed September 14, 2017

Flajšhans M, Hulák M, Kašpar V, Rodina M, Kocour M, Gela D 2009: Methodology of Preserving Genetic Fish Sources in a Live Gene Bank (in Czech). Edice Metodik, FROV JU Vodňany, No. 91, 35 p. (updated version 2015)

Flajšhans M, Kocour M, Ráb P, Hulák M, Petr J, Bohlen Šlechtová V, Šlechta V, Havelka M, Kašpar V, Linhart O 2013: Genetics and Breeding of Fish (in Czech). Fakulta rybářství a ochrany vod JCU, 305 p.

Gjedrem T 2000: Genetic improvement of cold-water fish species. Aquacult Res 31: 25-33

Gjedrem T 2005: Selection and Breeding Programs in Aquaculture. Springer, Dordrecht, The Netherlands, 364 p.

Gjedrem T 2012: Genetic improvement for the development of efficient global aquaculture: a personal opinion review. Aquaculture 44: 344-349

Gjedrem T, Robinson N, Rye M 2012: The importance of selective breeding in aquaculture to meet future demands for animal protein: a review. Aquaculture 350-353: 117-129

Henryon M, Berg P, Olesen NJ, Kjær TE, Slierendrecht WJ, Jokumsen A, Lund I 2005: Selective breeding provides an approach to increase resistance of rainbow trout (Onchorhynchus mykiss) to the diseases, enteric redmouth disease, rainbow trout fry syndrome, and viral haemorrhagic septicaemia. Aquaculture 250: 621-636

Horký P 2015: Freshwater resources and fisheries in the Czech Republic. In Craig JF: Fresh Water Fisheries Ecology, 920 p.

International Council for the Exploration of the Sea 2008: Report of the Working Group on the Application of Genetics in Fisheries and Mariculture (WGAGFM)

Iversen M, Finstad B, Nilssen K 1998: Recovery from loading and transport stress in Atlantic salmon (Salmo salar L.) smolts. Aquaculture 168: 387-394

Jackson TR, Ferguson MM, Danzmann RG, Fishback AG, Ihssen PE, O’Connell M, Crease TJ 1998: Identification of two QTL influencing upper temperature tolerance in three rainbow trout (Oncorhynchus mykiss) half-sib families. Heredity 80: 143-151

Janssen K, Chavanne H, Berentsen P, Komen H 2015: Rainbow trout (Oncorhynchus mykiss) - current status of selective breeding in Europe. Aquaculture Europe 1-12

Janssen K, Chavanne H, Berentsen P, Komen H 2017: Impact of selective breeding on European aquaculture. Aquaculture 472: 8-16

Jingou T, Xiaowen SUN 2015: Genetic and genomic analyses for economically important traits and their applications in molecular breeding of cultured fish Sci China Life Sci 58: 178-186

Johnson NA, Vallejo RL, Silverstein JT, Welch TJ, Wiens GD, Hallerman EM, Palti Y 2008: Suggestive association of major histocompatibility IB genetic markers with resistance to bacterial cold water disease in rainbow trout (Oncorhynchus mykiss). Marine Biotechnol 10: 429-437

Kean KS, AkiyukOi, Fusayuki N, Tetsuya A, Shinichi I, Nickolov R, Takashi S, Tetsuya A, Mamiko M, Ikuo D, Nobuaki O 2004: Identification of a novel chromosomal region associated with infectious hematopoietic necrosis (IHN) resistance in rainbow trout Oncorhynchus mykiss. Fish Pathol 39: 95-101

Lamaze M, Lashari P, Zhang Y, Sun X 2014: Identification of quantitative trait loci (QTLs) in aquaculture species. Rev Fisheries Sci \& Aquacult 22: 221-238

Lamaze FC, Pavey SA, Normandeau E, Roy G, Garant D, Bernatchez L 2014: Neutral and selective processes shape MHC gene diversity and expression in stocked brook charr populations (Salvelinus fontinalis). Molecular Ecol 23: 1730-1748

Leeds TDJ, Silverstein T, Weber GM, Vallejo RL, Palti Y, Rexroad CE, Evenhuis J, Hadidi S, Welch TJ, Wiens GD 2010: Response to selection for bacterial cold water disease resistance in rainbow trout. J Animal Sci 88: 1936-1946

Liu Z, Hu DD, Shao SJ, Yang J, Wang JF, Huang JQ 2013 Polymorphisms in MHC class Ia genes and resistance to IHNV in rainbow trout (Oncorhynchus mykiss). Genes Genomics 35: 587-595

Liu S, Vallejo RL, Gao G, Palti Y, Weber GM, Hernandez A, Roxroad CE 2015: Identification of single-nucleotide polymorphism markers associated with cortisol response to crowding in rainbow trout. Mar Biotechnol 17: 328-337

Magnadottir B 2010: Immunological control of fish diseases. Marine Biotechnol 12: 361-379

Markrigiannis AP, Anderson SK 2003: Regulation of natural killer cell function. Cancer Biol Ther 2: 610-616

Melamed P, Gong Z, Fletcher G, Hew ChL 2002: The potential impact of modern biotechnology on fish aquaculture. Aquaculture 204: 255-269

Nath S, Kales S, Fujiki K, Dixon B 2006: Major histocompatibility class II genes in rainbow trout (Oncorhynchus mykiss) exhibit temperature dependent downregulation. Immunogenetics 58: 443-453

Nichols KM, Bartholomew J, Thorgaard GH 2003a: Mapping multiple genetic loci associated with Ceratomyxa shasta resistance in Oncorhynchus mykiss. Dis Aquat Org 56: 145-154

Nichols KM, Young WP, Danzmann RG, Robison BD, Rexroad C, Noakes M, Phillips RB, Bentzen P, Spies I, 
Knudsen K, Allendorf FW, Cunningham BM, Brunelli J, Zhang H, Ristow S, Drew R, Brown KH,Wheeler PA, Thorgaard GH 2003b: A consolidated linkage map for rainbow trout (Oncorhynchus mykiss). Anim Genet 34: 102-115

Ødegård J, Baranski M, Gjerde B, Gjedrem T 2011: Methodology for genetic evaluation of disease resistance in aquaculture species: challenges and future prospects. Aquaculture Res 42: S103-S114

Okamoto N, Tayaman T, Kawanobe M, Fujiki N, Yasuda Y, Sano T 1993: Resistance of a rainbow trout strain to infectious pancreatic necrosis. Aquaculture 117: 71-76

Overturf K, LaPatra S, Towner R, Campbell N, Narum S 2010 Relationships between growth and disease resistance in rainbow trout, Oncorhynchus mykiss (Walbaum). J Fish Dis 33: 321-329

Ozaki A, Sakamoto T, Khoo S, Nakamura K, Coimbra MR, Akutsu T, Okamoto N 2001: Quantitative trait loci (QTLs) associated with resistance/susceptibility to infectious pancreatic necrosis virus (IPNV) in rainbow trout (Oncorhynchus mykiss). Mol Genet Genomics 265: 23-31

Ozaki A, Khoo S, Yoshiura Y, Ototake M, Sakamoto T, Dijkstra JM, Okamoto N 2007: Identification of additional quantitative trait loci (QTL) responsible for susceptibility to infectious pancreatic necrosis virus in rainbow trout. Fish Pathol 42: 131-140

Palíková M, Navrátil S, Mareš J 2015a: Preventive and prophylatic measures in intensive salmonid fish breeding - a review. Acta Univ Agricult Silvicult Mendel Brunensis 63: 1409-1416

Palíková M, Marková Z, Navrátil S, Mareš J, Papežíková I 2015b: Health problems of salmonid fish in recirculation systems of danish type under conditions of the Czech Republic. Veterinářství 65: 636-642

Palti Y, Nichols KM, Waller KI, Parsons JE, Thorgaard GH 2001: Association between DNA polymorphisms tightly linked to MHC class II genes and IHN virus resistance in backcrosses of rainbow and cutthroat trout. Aquaculture 194: 283-389

Paltia Y, Parsons JE, Thorgaard GH 1999: Identification of candidate DNA markers associated with IHN virus resistance in backcrosses of rainbow (Oncorhynchus mykiss) and cutthroat trout (O. clarki). Aquaculture 173: 81-94

Perry GML, Danzmann RG, Ferguson MM, Gibson JP 2001: Quantitative trait loci for upper thermal tolerance in outbred strains of rainbow trout (Oncorhynchus mykiss). Heredity 86: 333-341

Perry GML, Tarte P, Croisetiere S, Belhumeur P, Bernatchez L 2004: Genetic variance and covariance for $0+$ brook charr (Salvelinus fontinalis) weight and survival time of furunculosis (Aeromonas salmonicida) exposure. Aquaculture 235: 263-271

Perry GML, Ferguson M, Sakamoto T, Danzmann RG 2005: Sex-linked quantitative trait loci for thermotolerance and length in the rainbow trout. J Hered 96: 97-107

Plant KP, La Patra SE, Cain KD 2009: Vaccination of rainbow trout, Oncorhynchus mykiss (Walbaum), with recombinant and DNA vaccines produced to Flavobacterium psychrophilum heat shock proteins 60 and 70 . $\mathrm{J}$ Fish Dis 32: 521-534

Reiter RH 2006: Leistungs- und Qualitätseigenschaften jeweils zweier Herkünfte des Seesaiblings und des Bachsaiblings sowie ihrer Kreuzungen [Performance and quality characteristics of two sources of Arctic charr and brook trout and their crosses]. Dissertation: Technische Universität München, $193 \mathrm{p}$.

Rexroad CE, Vallejo RL, Liu S, Palti Y, Weber GM 2012: QTL affecting stress response to crowding in a rainbow trout broodstock population. BMC Genetics 13: 97

Rodriguez MF, LaPatra S, Williams S, Famula T, May B 2004: Genetic markers associated with resistance to infectious hematopoietic necrosis in rainbow and steelhead trout (Oncorhynchus mykiss) backcrosses. Aquaculture 241: 93-115

Roed KH, Brun E, Larsen HJ, Refstie T 1990: The genetic influence on serum haemolytic activity in rainbow trout (Oncorhynchus mykiss) selected for lysozyme activity. Aquaculture 209: 91-101

Rye M 2012: Current status and prospects for the application of genetic improvement in aquaculture species. In Symposium. Procedings of $9^{\text {th }}$ Biennial of the Brazilian Society of Animal Breeding, pp 20-22

Sauvage C, Vagner M, Derôme N, Audet C, Bernatchez L 2012: Coding gene SNP mapping reveals QTL linked to growth and stress response in brook charr (Salvelinus fontinalis). G3 Genes Genom Genet 2: 707-720

Silverstein JT, Vallejo RL, Palti Y, Leeds TD, Rexroad CE, Welch TJ, Wiens GD, Ducrocq V 2009: Rainbow trout resistance to bacterial cold-water disease is moderately heritable and is not adversely correlated with growth. J Anim Sci 87: 860-867

Sommerset I, Krossøy B, Biering E, Frost P 2005: Vaccines for fish in aquaculture. Expert Rev Vaccines 4: 89-101

Vallejo RL, Wiens GD, Rexroad CE, Welch TJ, Evenhuis JP, Leeds TD, Janss LLG, Palti Y 2010: Evidence of major genes affecting resistance to bacterial cold water disease in rainbow trout using bayesian methods of segregation analysis. J Anim Sci 88: 3814-3832

Vehviläinen H, Kause A, Quinton Ch, Koskinen H, Paananen T 2008: Survival of the currently fittest: genetics of rainbow trout survival across time and space. Genetics 180: 507-516

Weber GM, Vallejo RL 2008: Cortizol response to a crowding stress: heritability and association with disease resistance to Yersinia ruckeri in rainbow trout. N Am J Aquacult 70: 425-433 
Wenne R, Boudry P, Hemmer-Hansen J, Lubieniecki KP, Was A, Kause A 2007: What role for genomics in fisheries management and aquaculture? Aquatic Living Resources 20: 241-255

Yáñez JM, Houston RD, Newman S 2014: Genetics and genomics of disease resistance in salmonid species. Frontiers in Genetics 5: 415 